\title{
Sexual dimorphism in thyroid function and type 1 iodothyronine deiodinase activity in pre-pubertal and adult rats
}

\author{
Michelle P Marassi, Rodrigo S Fortunato, Alba C Matos da Silva, Valmara S Pereira, Denise P Carvalho, \\ Doris Rosenthal and Vânia M Corrêa da Costa
}

Laboratório de Fisiologia Endócrina, Instituto de Biofísica Carlos Chagas Filho, Universidade Federal do Rio de Janeiro, CCS-Bloco G-Cidade Universitária, Ilha do Fundão, Rio de Janeiro 21949-900, Brazil

(Requests for offprints should be addressed to V M Corrêa da Costa; Email: vmccosta@biof.ufrj.br)

\begin{abstract}
Iodothyronine deiodinase activities are regulated by sex steroids; however, the mechanisms underlying the reported sexual dimorphism are poorly defined. In the present report, we aimed to investigate whether type 1 deiodinase (D1) sexual dimorphism exists early in sexual development by studying pre-pubertal male $(\mathrm{Pm})$ and female $(\mathrm{Pf})$ rats, as well as adult controls $(\mathrm{C})$ and gonadectomized male and females rats. Adult male Wistar rats were studied 21 days after orchiectomy (Tex), and adult females were studied 21 days after ovariectomy $(\mathrm{Ovx})$, and after estradiol benzoate (Eb) replacement. Serum total triiodothyronine (T3) was higher in pre-pubertal (P) rats than in the matching adults, with no difference between genders, although in adult males T3 was significantly lower than in females. There were no sex or age differences in serum total T4. Serum TSH in pre-pubertal (P) rats was within the adult female range, and both were significantly lower than in adult males. D1 activity in liver was greater in Pm than in Pf. In adult females, liver D1 activity was lower, while in adult males it was higher than in P rats. The same pattern of D1 activity was found in kidney. In thyroid and pituitary, D1 activity was
\end{abstract}

similar in Pm, Pf, and adult females, which were all significantly lower than in the adult male. There were no differences in serum $\mathrm{T} 3$ and $\mathrm{T} 4$ between $\mathrm{C}$ and Tex males, but serum TSH was significantly decreased in Tex rats. Hepatic and renal D1 activities were lower in Tex than in $\mathrm{C}$, but no changes were detected in thyroid and pituitary. In Ovx females, T3 was significantly lower than in the $\mathrm{C}$ group. Serum T4 was significantly decreased by estradiol replacement therapy in Ovx rats, in both doses used, whereas TSH was unchanged. Eb replacement increased liver and thyroid D1 activity, but in the kidney, only the highest estradiol dose promoted a significant D1 increase. In conclusion, in males, hepatic and renal D1 activity appears to be significantly influenced by gonadal hormones, in contrast to females, in which only exogenous $\mathrm{Eb}$ treatment stimulated D1 activity. The comparison between pre-pubertal and adult rats suggests that serum T3 is not the main regulator of $\mathrm{D} 1$ activity, and other factors, besides $\mathrm{T} 3$ and gonadal hormones, can modulate D1 activity during murine maturation.

Journal of Endocrinology (2007) 192, 121-130

\section{Introduction}

Thyroxine (T4), the main secretory product of the thyroid gland, is converted into active (triiodothyronine; T3) or inactive (reverse T3; rT3) metabolites after deiodination of its outer $\left(5^{\prime}\right)$ or inner ring (5) respectively. Based on several functional criteria and molecular characterization, three distinct deiodinase enzymes have been identified: type 1 (D1), type 2 (D2), and type 3 (D3). D1 seems to be the only selenodeiodinase that can function as either an outer or inner ring iodothyronine deiodinase, while D2 and D3 are exclusively outer (D2) or inner (D3) deiodinases respectively. D1 is expressed in many tissues, such as liver, kidney, thyroid gland, central nervous system, pituitary, intestine, placenta, and others (St Germain 1994, Bianco et al. 2002).

The prevalence of thyroid dysfunction is greater in women than in men. These disorders often appear concomitantly with changes in endogenous levels of sex steroids, in particular during puberty, pregnancy, and at the time of menopause. Besides this clinical aspect, various experimental studies with rats have established that sex hormones influence thyroid function, but the nature and significance of this influence have yet to be ascertained (Donda et al. 1990).

Cheron et al. (1980) reported lower serum T3 and higher serum thyroid-stimulating hormone (TSH) in adults than in 21- and 30-day-old pre-pubertal male ( $\mathrm{Pm})$ rats, without any significant difference in serum $\mathrm{T} 4$. The T4-5' -monodeiodination rates in liver homogenates were lower in $2-, 4-$, and 9-day-old rats than adults, reaching the adult value in 21-dayold rats; however, the intrapituitary $\mathrm{T} 4-5^{\prime}$-monodeiodination rate was higher in 2- and 4-day-old rats and fell to the adult values by 30 days of age.

In the adult rat, numerous sex-related differences in thyroid function have been reported, in particular lower plasma $\mathrm{T} 4$ and 
TSH concentrations associated with a higher plasma T3 level in the female than in the male rats (Rapp \& Pyun 1974, Fukuda et al. 1975, Greeley et al. 1983, Chen 1984, Corrêa da Costa et al. 2001, Moreira et al. 2005). Some studies demonstrated that liver D1 activity in females is lower than in male rats (Harris et al. 1979, Donda et al. 1990, Santini et al. 1994, Miyashita et al. 1995) and pituitary D1 activity in males is lower than in female rats (Donda et al. 1990, Köhrle et al. 1995).

Liver D1 activity is significantly decreased in orchiectomized rats and increased by testosterone administration. Besides, pituitary D1 activity is increased in castrated male rats, and testosterone administration does not affect pituitary D1 activity (Lisbôa et al. 2001). In contrast to male rats, several reports have shown that ovariectomy or $\beta$-estradiol administration does not alter liver D1 activity in female rats (Harris et al. 1979, Miyashita et al. 1995). However, Lisbôa et al. (1997, 2001) reported that ovariectomy produced a decrease in both liver and pituitary D1 activities and that treatment with estradiol was able to return these activities to control levels and to significantly increase thyroid D1.

The respective roles of androgens and estrogens on rat thyroid function are a matter of debate, since the previous studies are controversial. Probably, the inconclusive previous reports are due not only to different rat strains used, but mainly to the different developmental stages that have been studied. Hence, the aim of the present study was to further evaluate the sex-related differences found in thyroid function and D1 activity by comparing pre-pubertal rats, adult control, and gonadectomized rats. In the first phase of this study, we compared pre-pubertal with adult rats to assess the effects of emerging gonadal function on pituitary-thyroid axis regulation. In an attempt to better understand the respective roles of androgens and estrogens, in the second protocol, using only adult rats, we carried out the removal of gonads to evaluate the importance of gonadal hormones on thyroid function.

\section{Materials and Methods}

\section{Animals}

The study was approved by the Institutional Committee for Use of Animals in Research, and the procedures used were in compliance with the International Guiding Principles for Biomedical Research Involving Animals, the Council for International Organizations of Medical Sciences (Geneva, Switzerland), and the guiding principles for care and use of animals from the American Physiological Society. Pre-pubertal male (80-100 g) and female (70-90 g), and adult male (250-300 g) and female (200-250 g) Wistar rats were kept from birth in a temperature-controlled $\left(22-25{ }^{\circ} \mathrm{C}\right)$ animal room, with a $12 \mathrm{~h}$ light: $12 \mathrm{~h}$ darkness cycle, and pelleted commercial chow (Paulínea, São Paulo, Brazil; iodine content $2 \mathrm{mg} / \mathrm{kg}$ ) and water were available ad libitum.

\section{Experimental groups}

Pre-pubertal animals did not suffer any treatment. Adult male animals were divided into two groups: sham-operated (control) and orchiectomized (Tex) rats killed 21 days after the surgery. All adult female rats showed a regular 4-5 day estrous cycle monitored by vaginal cytology collected each morning for 2 consecutive weeks before starting the experiments. Adult female rats were divided into four groups: sham-operated (control), ovariectomized treated with vehicle $(\mathrm{Ovx})$, or treated with $17 \beta$-estradiol benzoate (Eb; Sigma), in a physiological dose of $0.7 \mu \mathrm{g} / 100 \mathrm{~g}$ body weight per day $(\mathrm{Ovx}+0.7)$, or in a supraphysiological dose of $14 \mu \mathrm{g} / 100 \mathrm{~g}$ bw per day (Ovx + 14), administered subcutaneously for 21 days. The pre-pubertal and adult animals were killed by decapitation and blood was collected for hormone concentration analyses. Serum was obtained after centrifugation of the blood at 3000 r.p.m. for $20 \mathrm{~min}$ and stored at $-20{ }^{\circ} \mathrm{C}$. Rat tissues (liver, kidney, thyroid, and pituitary) were dissected out and stored at $-70{ }^{\circ} \mathrm{C}$ until processing for enzymatic measurements.

\section{RIA for estradiol and testosterone}

Serum total estradiol and testosterone were determined by specific Coated-Tube RIA kits (estradiol: DSL-4400, EUA; testosterone: DSL-4100, EUA). All the procedures were carried out following the fabricant recommendations.

\section{RIA for total T3, T4, and TSH}

The measurement of serum TSH levels was carried out using a specific RIA for rat TSH obtained from the National Institute of Diabetes, Digestive and Kidney Diseases (NIDDK, Bethesda, EUA), and expressed in terms of reference preparations 3 (RP-3).

Serum T3 and T4 were determined by specific Coated-Tube RIA kits (T3: DLS-3100 Active TX, EUA; T4: DLS-3200 Active TX, EUA). Hormone-stripped rat serum was used for the standard curves of total T3, T4, and TSH. All the procedures were carried out following the fabricant recommendations.

\section{Type 1 iodothyronine deiodinase activity}

The type 1 activity was determined using methods previously published (Berry et al. 1991), as adapted by A C Bianco and P R Larsen (personal communication). In short, each thyroid, pools of two pituitary glands, and $25 \mathrm{mg}$ liver and kidney were homogenized in $1 \mathrm{ml} 0 \cdot 1 \mathrm{M}$ sodium phosphate buffer containing $1 \mathrm{mM}$ EDTA, $0.25 \mathrm{M}$ sucrose, and $10 \mathrm{mM}$ dithiothreitol, $\mathrm{pH}$ 6.9. Homogenates $(150 \mu \mathrm{g}$ protein for pituitary samples and $30 \mu \mathrm{g}$ protein for liver, thyroid, and kidney) were incubated, in duplicate, for $1 \mathrm{~h}$ at $37^{\circ} \mathrm{C}$ with $1 \mu \mathrm{M} \mathrm{rT3}$ (Sigma), freshly purified (Sephadex LH20) tracer $\left.{ }^{125} \mathrm{I}\right] \mathrm{rT3}$ (Perkin-Elmer Life Sciences, Boston, MA, USA), and $10 \mathrm{mM}$ dithiothreitol in $100 \mathrm{mM}$ potassium phosphate buffer, $\mathrm{pH} 6 \cdot 9$, containing $1 \mathrm{mM}$ EDTA. Total reaction 
volume was $300 \mu \mathrm{l}$. Blank incubations were carried out in the absence of protein. The reaction was stopped in an ice-bath followed by immediate addition of $200 \mu \mathrm{l}$ fetal bovine serum (Cultilab, BR) and $100 \mu \mathrm{l}$ trichloroacetic acid (50\%, v/v). After thorough mixing (Vortex), the samples were centrifuged at $8000 \mathrm{~g}$ for $3 \mathrm{~min}$, and an aliquot of the supernatant was collected for measurement of ${ }^{125} \mathrm{I}$ liberated during the deiodination reaction. The specific enzyme activity was expressed as picomoles of rT3 deiodinated/min mg protein. Although type 2 deiodinase (D2) can also be present in the thyroid and pituitary glands, in our assay conditions only D1 activity is measured since deiodinase activities were completely blocked in the presence of $100 \mathrm{mM}$ propylthiouracil (PTU), a specific D1 inhibitor (data not shown).

Protein was measured by the Bradford method (Bradford 1976), after incubation of homogenates with $\mathrm{NaOH}(2 \cdot 5 \mathrm{M})$ for $30 \mathrm{~min}$ at room temperature.

\section{Statistical analyses}

We used at least four animals in each experimental group and the experiments were repeated thrice. Data from total T3, T4, and deiodinase activities are expressed as means \pm s.E.M. and were analyzed by two-way ANOVA using the SuperANOVA program (Abacus Concept, Berkeley, CA, USA), by one-way ANOVA, or by unpaired $t$-test using the Graphpad Prism software (version 4, Graphpad Software, Inc., San Diego, USA). The results of serum TSH, estradiol, and testosterone, which do not have a normal distribution, are expressed as median and minimum-maximum values and were analyzed by non-parametric ANOVA (Kruskal-Wallis test) or by MannWhitney test, using the Graphpad Prism software (version 4, Graphpad Software, Inc., San Diego, USA). A value of $P \leq 0 \cdot 05$ was considered statistically significant.

\section{Results}

\section{Pre-pubertal versus adult rats}

Serum total T3, T4, and TSH concentrations Serum total T3 did not differ between female and male pre-pubertal rats, but was higher in adult female than in adult male rats. Moreover, serum T3 was significantly higher in pre-pubertal rats than in adult animals. Serum total T4 was not significantly different among the groups studied. Serum TSH levels were not different between pre-pubertal and female adult rats, but were significantly higher in male adults when compared with the other groups (Table 1).

D1 activity Liver and renal D1 activities were significantly higher in male than in female pre-pubertal rats (liver, male prepubertal $=80 \cdot 1 \pm 4 \cdot 7$ and female pre-pubertal $=61 \cdot 4 \pm 2 \cdot 6$; renal, male pre-pubertal $=70 \cdot 7 \pm 3 \cdot 2$ and female pre-puber$\mathrm{tal}=62 \cdot 9 \pm 1 \cdot 3$ pmoles $\mathrm{rT} 3 / \mathrm{min} \mathrm{mg}$ protein). The liver and renal D1 activities were markedly higher in male adult rats than in pre-pubertal and female adult animals (liver, male adult $=$ $95 \cdot 9 \pm 3 \cdot 2$ and female adult $=28 \cdot 2 \pm 2 \cdot 1$; renal, male adult $=$ $96 \cdot 8 \pm 2 \cdot 4$ and female adult $=41 \cdot 2 \pm 2 \cdot 8$ pmoles $\mathrm{rT} 3 / \mathrm{min} \mathrm{mg}$ protein). However, liver and renal D1 activities were lower in female adult rats than in pre-pubertal rats (Fig. 1A and B).

In the thyroid and pituitary, D1 activities did not differ between female and male pre-pubertal rats (thyroid, male prepubertal $=39 \cdot 7 \pm 2 \cdot 4$ and female pre-pubertal $=40 \cdot 7 \pm 2 \cdot 9$; pituitary, male pre-pubertal $=1.40 \pm 0.3$ and female prepubertal $=2 \cdot 27 \pm 0 \cdot 8$ pmoles $\mathrm{rT} 3 / \mathrm{min} \mathrm{mg}$ protein), but it was significantly higher in male adults than in pre-pubertal and female adult rats (thyroid, male adult $=126 \cdot 2 \pm 6 \cdot 6$ and female adult $=48 \cdot 3 \pm 3 \cdot 6$; pituitary, male adult $=3 \cdot 33 \pm 0 \cdot 3$ and female adult $=1 \cdot 85 \pm 0 \cdot 3$ pmoles $\mathrm{rT} 3 / \mathrm{min} \mathrm{mg}$ protein) (Fig. 1C and D).

\section{Adult male rats}

Body and tissue weights Body weight gain was significantly impaired in castrated male (Tex) rats in comparison with control animals (Fig. 2).

The absolute and relative thyroid and pituitary weights were not statistically different between control and Tex groups (thyroid: control $=16 \cdot 27 \pm 0.65 \mathrm{mg}$ or $46 \cdot 76 \pm 1 \cdot 79 \mu \mathrm{g} / \mathrm{g}$ bw, $n=30 ;$ Tex $=15 \cdot 37 \pm 0.66 \mathrm{mg}$ or $45 \cdot 71 \pm 1.93 \mu \mathrm{g} / \mathrm{g}$ bw, $n=19$ and pituitary: control $=9 \cdot 53 \pm 0.27 \mathrm{mg}$ or $27 \cdot 61 \pm 1 \cdot 02 \mu \mathrm{g} / \mathrm{g}$ bw, $n=30 ;$ Tex $=10 \cdot 26 \pm 0 \cdot 34 \mathrm{mg}$ or $30 \cdot 95 \pm 1 \cdot 46 \mu \mathrm{g} / \mathrm{g}$ bw, $n=19)$.

\section{Serum total testosterone, T3, T4, and TSH}

concentrations Serum testosterone and TSH were significantly decreased in the Tex group despite the fact that serum T3 and T4 were unchanged (Table 2).

Table 1 Serum total T3, T4, and TSH concentrations in pre-pubertal and adult, female and male rats. Data are shown as mean \pm S.E.M. TSH is presented as median (minimum-maximum); $n=$ total number of rats.

\begin{tabular}{|c|c|c|c|c|}
\hline & \multicolumn{2}{|l|}{ Pre-pubertal rats } & \multicolumn{2}{|l|}{ Adult rats } \\
\hline & Female & Male & Female & Male \\
\hline T3 (ng/dl) & $105 \cdot 3 \pm 4 \cdot 69^{\mathrm{a}}(n=17)$ & $105 \cdot 1 \pm 3 \cdot 52^{\mathrm{a}}(n=17)$ & $74 \cdot 02 \pm 6 \cdot 25^{\mathrm{b}}(n=21)$ & $50 \cdot 82 \pm 5 \cdot 58^{\mathrm{c}}(n=27)$ \\
\hline $\mathrm{T} 4(\mu \mathrm{g} / \mathrm{dl})$ & $1 \cdot 62 \pm 0 \cdot 14^{\mathrm{a}}(n=17)$ & $1 \cdot 95 \pm 0 \cdot 17^{\mathrm{a}, \mathrm{b}}(n=17)$ & $2 \cdot 15 \pm 0 \cdot 16^{\mathrm{a}, \mathrm{b}}(n=22)$ & $2 \cdot 21 \pm 0 \cdot 22^{\mathrm{b}}(n=25)$ \\
\hline $\mathrm{TSH}(\mathrm{ng} / \mathrm{ml})$ & $0.97(0 \cdot 81-1 \cdot 30)^{\mathrm{a}}(n=17)$ & $1 \cdot 11(0 \cdot 74-1 \cdot 92)^{\mathrm{a}}(n=17)$ & $1 \cdot 05(0 \cdot 76-1 \cdot 90)^{\mathrm{a}}(n=23)$ & $1 \cdot 37(0 \cdot 81-3 \cdot 11)^{\mathrm{b}}(n=24)$ \\
\hline
\end{tabular}

Different letters indicate statistically significant differences for: T3, $P<0 \cdot 001 ; \mathrm{T} 4, P<0 \cdot 05 ; \mathrm{TSH}, P<0 \cdot 001 \mathrm{~b}$ vs pre-pubertal female and $P<0 \cdot 05 \mathrm{~b}$ vs other groups. 


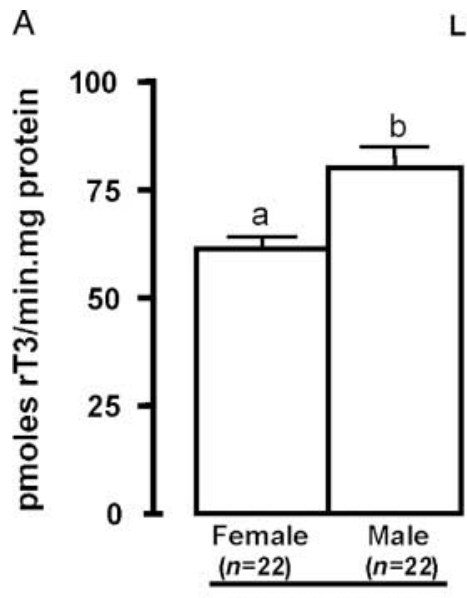

Pre-pubertal
Liver D1

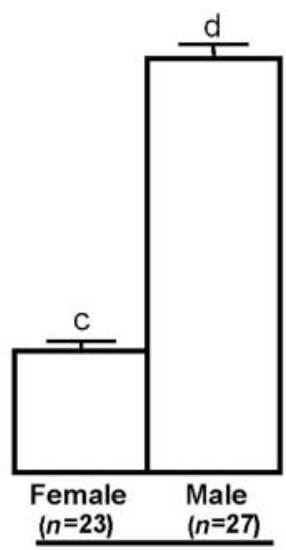

Adults

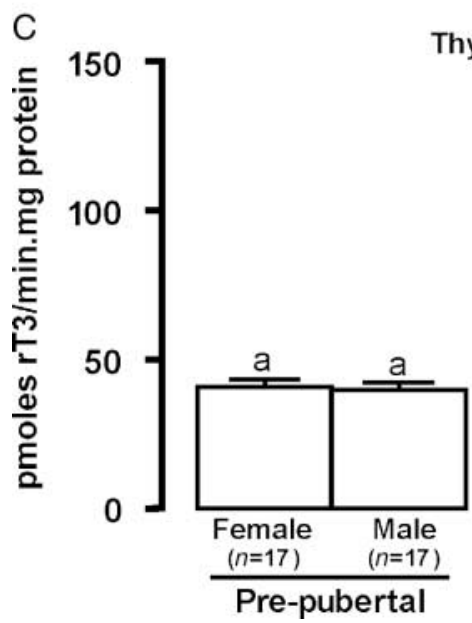

Thyroid D1

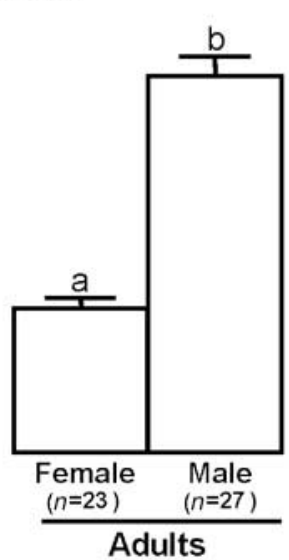

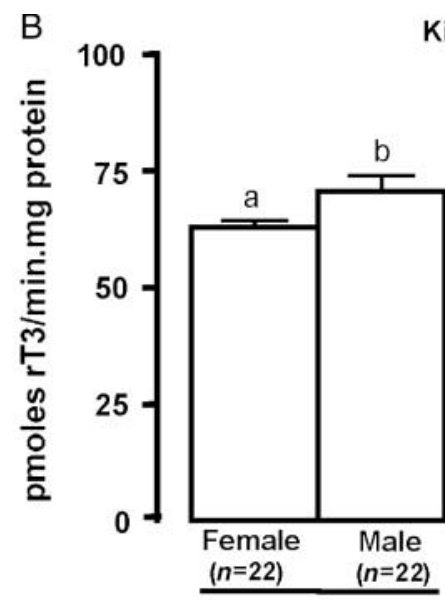

Pre-pubertal
Kidney D1

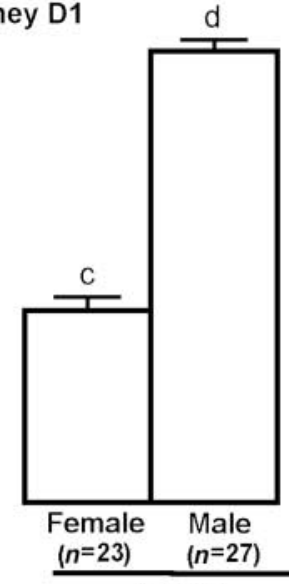

Adults

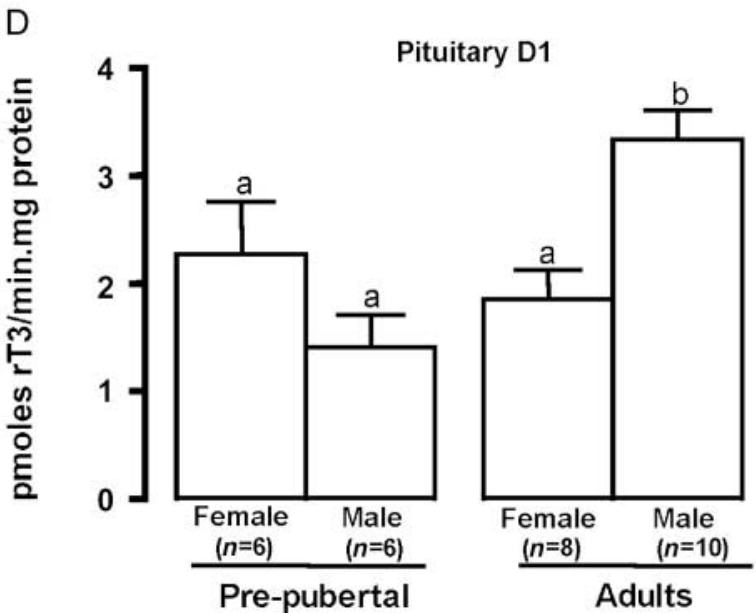

Figure 1 Type 1 iodothyronine deiodinase activity in liver (A), kidney (B), thyroid (C), and pituitary (D) from pre-pubertal and adult, female and male rats. Data are shown as mean \pm S.E.M.; $n=$ total number of rats. Different letters indicate statistically significant differences for: liver, $P<0.001$; kidney, $P<0 \cdot 05$ a versus $b$ and $P<0.001$ a versus other groups; thyroid, $P<0 \cdot 001 ;$ pituitary, $P<0 \cdot 01$.

D1 activity Hepatic D1 activity was significantly decreased in the Tex group (control $=92 \cdot 6 \pm 3 \cdot 45, \quad$ Tex $=63 \cdot 7 \pm$ $3 \cdot 40$ pmoles $\mathrm{rT} 3 / \mathrm{min} \cdot \mathrm{mg}$ protein; Fig. 3A) as was the renal D1 activity (control $=94 \cdot 3 \pm 2 \cdot 56$, Tex $=84 \cdot 1 \pm 4 \cdot 69$ pmoles $\mathrm{rT} 3 / \mathrm{min} \cdot \mathrm{mg}$ protein; Fig. 3B). However, thyroidal D1 activity was unchanged in the castrated group (control $=127 \cdot 5 \pm 6 \cdot 23$, Tex $=126 \cdot 9 \pm 9 \cdot 36$ pmoles $\mathrm{rT3} / \mathrm{min} \cdot \mathrm{mg}$ protein; Fig. 3C), regardless of diminished serum TSH. In the pituitary, D1 activity was also unchanged by castration (control $=2 \cdot 81 \pm 0 \cdot 35$, Tex $=$ $2 \cdot 53 \pm 0 \cdot 52$ pmoles $\mathrm{rT} 3 / \mathrm{min} \cdot \mathrm{mg}$ protein; Fig. 3D).

\section{Adult female rats}

Body and tissue weights Body weight gain was significantly higher in ovariectomized (Ovx) rats during the second and third weeks after castration in comparison with control animals, as previously described in the literature (Kimura et al. 2002). Estradiol replacement therapy was able to circumvent the higher body weight gain caused by ovariectomy. In fact, body weight gain in Ovx rats treated with $0.7 \mu \mathrm{g} / 100 \mathrm{~g}$ bw estradiol benzoate $(\mathrm{Ovx}+0 \cdot 7)$ was lower than in the Ovx and control groups. When Ovx rats

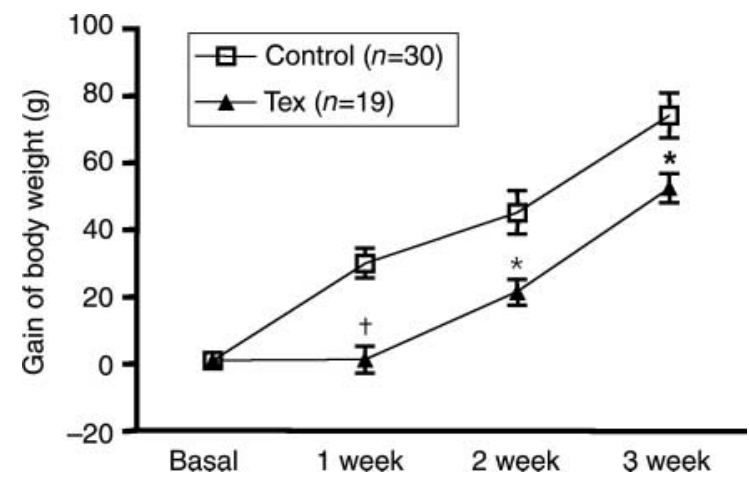

Figure 2 Body weight gain in adult sham-operated (control) and castrated (Tex) male rats. Data are shown as means \pm S.E.M.; $n=$ total number of rats. ${ }^{*} P<0 \cdot 05,{ }^{\dagger} P<0 \cdot 01$. 
Table 2 Effects of orchiectomy on serum total testosterone, T3, T4, and TSH concentrations. Data are shown as mean \pm s.E.M., testosterone and TSH are presented as median (minimum-maximum); $n=$ total number of rats.

\begin{tabular}{|c|c|c|c|c|}
\hline & Testosterone (ng/ml) & T3 (ng/dl) & $\mathbf{T 4}(\mu \mathrm{g} / \mathrm{dl})$ & TSH $(\mathrm{ng} / \mathrm{ml})$ \\
\hline Cont & $3 \cdot 92(1 \cdot 13-15 \cdot 59)(n=15)$ & $54 \cdot 76 \pm 5 \cdot 62(n=30)$ & $2 \cdot 18 \pm 0 \cdot 20(n=28)$ & $1 \cdot 45(0 \cdot 81-3 \cdot 35)(n=26)$ \\
\hline Tex & $<0 \cdot 1^{\dagger}(n=17)$ & $56 \cdot 53 \pm 6 \cdot 04(n=19)$ & $1 \cdot 99 \pm 0 \cdot 19(n=16)$ & $1.19(0.91-1.98)^{*}(n=19)$ \\
\hline
\end{tabular}

$* P<0 \cdot 05,{ }^{+} P<0 \cdot 0001$.

were treated with $14 \mu \mathrm{g} / 100 \mathrm{~g}$ bw estradiol benzoate (Ovx + 14), the body weight gain was significantly decreased during the 3 weeks of evaluation in comparison with Ovx and control rats (Fig. 4).

The absolute thyroid weight was not statistically different among control, Ovx, Ovx $+0 \cdot 7$, and Ovx +14 groups (control $=13 \cdot 70 \pm 0.34 \mathrm{mg}, n=27 ; \quad$ vvx $=13.53 \pm 0.60 \mathrm{mg}$, $n=15 ;$ Ovx $+0 \cdot 7=13 \cdot 13 \pm 0.73 \mathrm{mg}, \quad n=16 ;$ Ovx $+14=$ $14.38 \pm 0.57 \mathrm{mg}, n=16)$. On the other hand, the absolute pituitary weight was statistically increased in Ovx +0.7 and Ovx +14 rats in comparison with the two other groups (control $=10.41 \pm 0.52 \mathrm{mg}, n=27 ;$ Ovx $=9.73 \pm 0.49 \mathrm{mg}$, $n=15 ;$ Ovx $+0 \cdot 7=16 \cdot 38 \pm 0.69 \mathrm{mg}, n=16 ;$ Ovx $+14=$ $32 \cdot 13 \pm 2 \cdot 86 \mathrm{mg}, n=16$ ), as previously described (Scheithauer et al. 1990). Pituitaries from rats treated with the higher estradiol dose $(\mathrm{Ovx}+14)$ were even heavier than in Ovx $+0 \cdot 7$.

Serum total estradiol, T3, T4, and TSH concentrations Serum estradiol was decreased by ovariectomy, and this decrease was reversed by estradiol $0.7 \mu \mathrm{g} / 100 \mathrm{~g}$ bw, although these changes do not reach significance. In the rats that received the supraphysiological dose of estradiol $(14 \mu \mathrm{g} / 100 \mathrm{~g} \mathrm{bw})$, serum estradiol was significantly higher than in control and Ovx groups. Serum total T3 was lower in the Ovx group than in control rats and both doses of estradiol normalized serum T3. Serum total T4 was not significantly changed by ovariectomy, but estradiol benzoate administration $(\mathrm{Ovx}+0.7$ and $\mathrm{Ovx}+14)$ significantly decreased
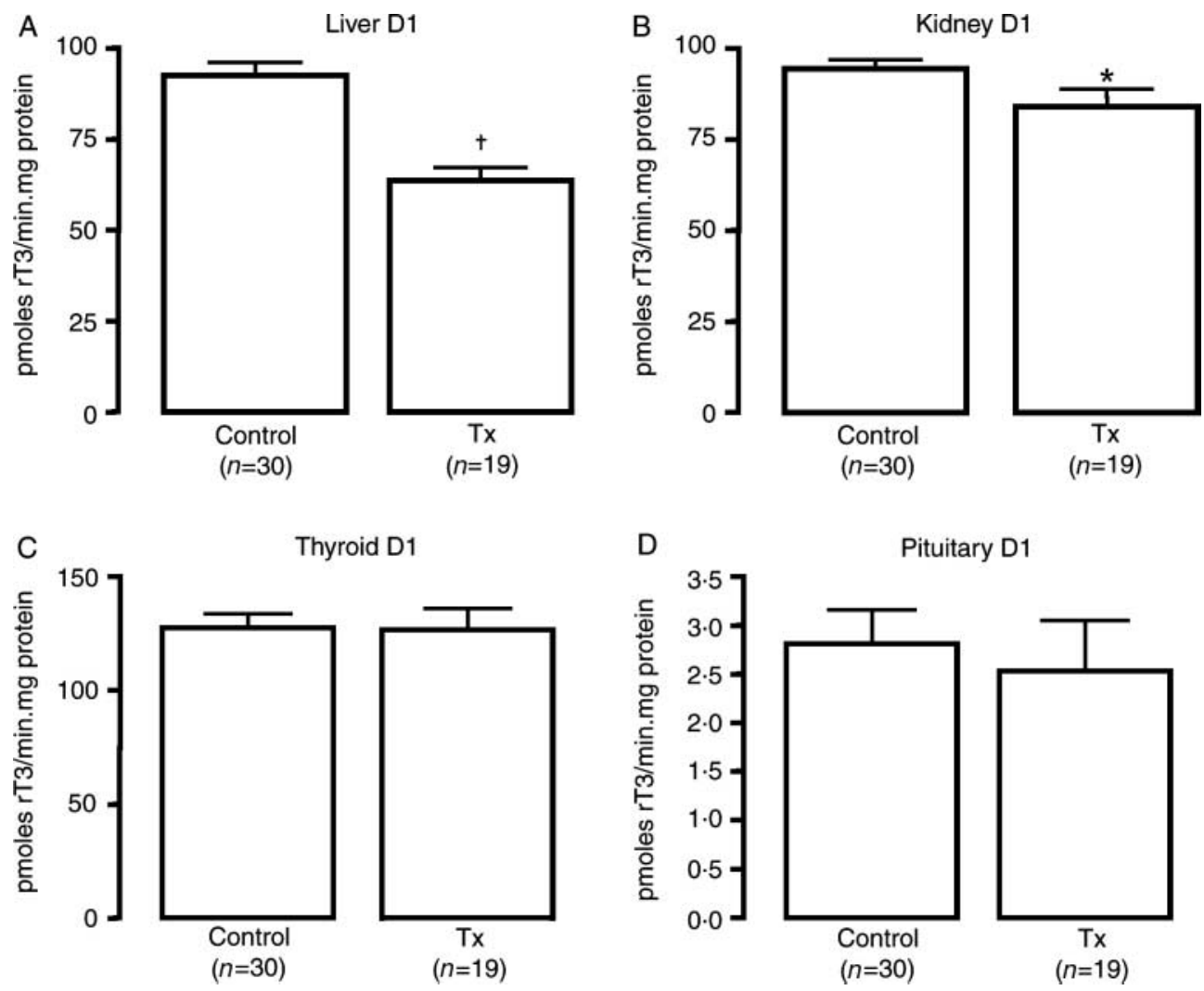

Figure 3 Type 1 iodothyronine deiodinase activity in liver (A), kidney (B), thyroid (C), and pituitary (D) of male sham-operated (control) and castrated (Tx) rats killed 3 weeks after castration. Data are shown as means \pm S.E.M.; $n=$ total number of rats. ${ }^{*} P<0 \cdot 05,{ }^{+} P<0 \cdot 001$. 


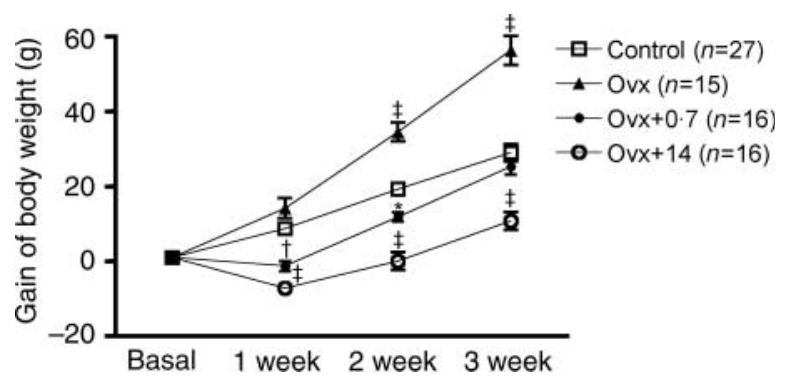

Figure 4 Body weight gain in adult female sham-operated (control) and ovariectomized rats treated with vehicle (Ovx) or with 0.7 $(\mathrm{Ovx}+0 \cdot 7)$ or $14(\mathrm{Ovx}+14) \mu \mathrm{g} / 100 \mathrm{~g}$ bw per day estradiol benzoate, subcutaneously for 21 days. Data are shown as means \pm S.E.M.; $n=$ total number of rats. ${ }^{*} P<0 \cdot 05,{ }^{\dagger} P<0 \cdot 01,{ }^{\ddagger} P<0 \cdot 001$ vs control.

serum T4 in comparison with the control group. Serum TSH levels did not differ among these groups (Table 3).

D1 activity Liver, renal, thyroid, and pituitary D1 activities were not significantly modified by ovariectomy. However, liver D1 activity was higher in $\mathrm{Ovx}+0 \cdot 7$ and $\mathrm{Ovx}+14$ than in control rats (control $=30 \cdot 3 \pm 2 \cdot 05, \quad$ Ovx $=30 \cdot 5 \pm 2 \cdot 04$, $\mathrm{O} v x_{\mathrm{v}}+0 \cdot 7=37 \cdot 0 \pm 1 \cdot 92, \mathrm{Ovv}_{\mathrm{v}}+14=36 \cdot 7 \pm 2 \cdot 79$ pmoles rT3/min·mg protein; Fig. 5A). Renal D1 activity (Fig. 5B) was significantly increased in the ovariectomized rats treated with the highest estradiol benzoate dose $(\mathrm{Ovx}+14)$ in comparison with control and Ovx animals (control $=43 \cdot 3 \pm$ $2 \cdot 73, \mathrm{Ovx}_{\mathrm{v}}=42 \cdot 5 \pm 2 \cdot 73, \mathrm{Ovv}_{\mathrm{v}}+0 \cdot 7=51 \cdot 0 \pm 2 \cdot 11, \mathrm{Ovx}+$ $14=53 \cdot 2 \pm 4 \cdot 32 \mathrm{pmoles} \mathrm{rT} 3 / \mathrm{min} \cdot \mathrm{mg}$ protein). The thyroid D1 activity was significantly higher in Ovx $+0 \cdot 7$ and Ovx + 14 than in controls and Ovx rats (control $=56 \cdot 9 \pm 5 \cdot 11$, $\mathrm{Ovx}=57 \cdot 4 \pm 5 \cdot 35, \mathrm{Ovx}+0 \cdot 7=84 \cdot 2 \pm 10 \cdot 54, \mathrm{Ovx}+14=$ $79 \cdot 4 \pm 6 \cdot 91 \mathrm{pmoles} \mathrm{rT} 3 / \mathrm{min} \cdot \mathrm{mg}$ protein; Fig. $5 \mathrm{C})$. In the pituitary, D1 enzyme activity did not change (control $=1 \cdot 62 \pm$ $0 \cdot 25, \mathrm{Ovx}_{\mathrm{v}}=1 \cdot 54 \pm 0 \cdot 29, \mathrm{Ovx}_{\mathrm{v}}+0 \cdot 7=2 \cdot 14 \pm 0 \cdot 57, \mathrm{Ovx}+$ $14=1 \cdot 67 \pm 0 \cdot 26 \mathrm{pmoles} \mathrm{rT} 3 / \mathrm{min} \cdot \mathrm{mg}$ protein; Fig. $5 \mathrm{D})$.

\section{Discussion}

There is not much information about sex-related differences in thyroid function of pre-pubertal rats. In the present study, we found no statistically significant differences in serum total T3, T4, and TSH between male and female pre-pubertal rats, but liver and renal D1 activities were significantly higher in male than in female animals. There are evident pre-pubertal surges in estradiol (Meijs-Roelofs et al. 1973) and testosterone (Dohler \& Wuttke 1975) during the first 3 postnatal weeks. Banu et al. (2002) reported that both testosterone (in males) and estradiol (in females) regulate TSH receptor levels in the immature rat thyroid, suggesting that postnatal elevation of sex steroids might have a physiological relevance to the TSHinduced mitogenic activity in thyrocytes. The postnatal surge in sex steroids might play a relevant role with respect to sexrelated differences in D1 activity in pre-pubertal rats. Early testosterone surge might play an important role in the regulation of liver D1 activity in immature rats, and future experiments in this area might enlighten this issue.

During the early postnatal period (pre-puberty), serum testosterone and estradiol are markedly lower than in the adult phase (Banu \& Aruldhas 2002). Comparing thyroid function in pre-pubertal and adult rats from both genders, we found no differences in total serum T4, but serum total T3 was higher in pre-pubertal than in adult rats, and serum TSH was higher in male adults than in pre-pubertal and female rats. These results are in accordance with the previous reports (Cheron et al. 1980, Banu \& Aruldhas 2002) that showed serum TSH to be higher in male adults than in 30-day-old rats, without differences in serum $\mathrm{T} 4$.

In accordance with the previous reports (Donda et al. 1987, Corrêa da Costa et al. 2001, Moreira et al. 2005), we found higher serum $\mathrm{T} 3$ in female than in male adult rats. T4 sulfation decreases the outer ring deiodination of $\mathrm{T} 4$ and increases its inner ring deiodination, generating rT3. Hepatic sulfotransferase activities, responsible for $\mathrm{T} 4$ sulfation, are higher in male than in female adult rats (Gong et al. 1992, Santini et al. 1994, Visser et al. 1998), which could contribute to the decreased serum T3 levels in males.

In addition to higher serum T3, we detected lower serum TSH in female than in male adult rats, which also agrees with the previous studies (Rapp \& Pyun 1974, Fukuda et al. 1975, Farbota et al. 1987, Santini et al. 1994). In relation to serum $\mathrm{T} 4$, we did not find sex-related differences, as reported by Harris et al. (1979), Christianson et al. (1981) and Santini et al. (1994), but this data disagree with those from Rapp \& Pyun (1974) and Fukuda et al. (1975), who observed higher serum $\mathrm{T} 4$ in male than in female adult rats.

Cheron et al. (1980) reported that liver D1 activities in 2-, 4-, and 9-day-old rats were lower than the adult values,

Table 3 Effects of ovariectomy and treatment of ovariectomized rats with different doses of estrogen on serum total estradiol, T3, T4, and TSH concentrations. Data are shown as means \pm S.E.M., estradiol and TSH are presented as median (minimum-maximum); $n=$ total number of rats.

\begin{tabular}{|c|c|c|c|c|}
\hline & Estradiol (pg/ml) & T3 (ng/dl) & $\mathbf{T 4}(\mu \mathrm{g} / \mathrm{dl})$ & TSH (ng/ml) \\
\hline Control & $25 \cdot 1(15 \cdot 3-56 \cdot 1)(n=10)$ & $79 \cdot 16 \pm 5 \cdot 81(n=25)$ & $2 \cdot 16 \pm 0 \cdot 15(n=24)$ & $1 \cdot 11(0.67-3 \cdot 03)(n=27)$ \\
\hline Ovx & $16 \cdot 2(9 \cdot 74-28 \cdot 9)(n=10)$ & $60 \cdot 78 \pm 7 \cdot 73 *(n=14)$ & $2 \cdot 03 \pm 0 \cdot 18(n=14)$ & $1 \cdot 17(0 \cdot 81-2 \cdot 95)(n=15)$ \\
\hline Ovx $+0 \cdot 7$ & $37 \cdot 6(19 \cdot 1-79 \cdot 8)(n=10)$ & $76 \cdot 06 \pm 6 \cdot 51(n=16)$ & $1 \cdot 69 \pm 0 \cdot 10^{*}(n=14)$ & $1 \cdot 27(0.92-1 \cdot 88)(n=16)$ \\
\hline Ovx +14 & $585(262-3166)^{\dagger} \#(n=10)$ & $74 \cdot 86 \pm 5 \cdot 45(n=16)$ & $1 \cdot 70 \pm 0 \cdot 15^{*}(n=14)$ & $1 \cdot 25(0 \cdot 82-2 \cdot 25)(n=16)$ \\
\hline
\end{tabular}

$* P<0 \cdot 05,{ }^{\dagger} P<0 \cdot 01$ vs control; \#, $P<0 \cdot 001$ vs OVX 
A



Liver D1

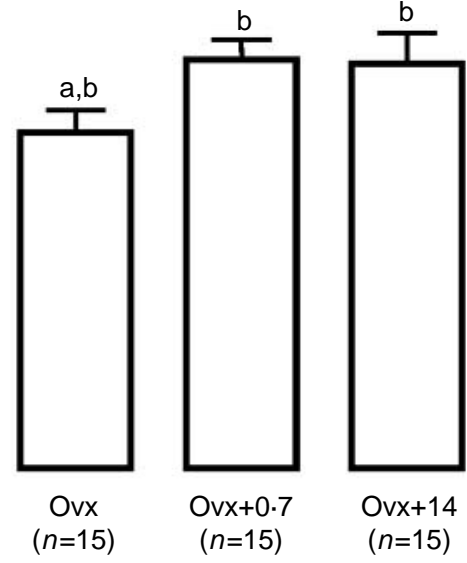

B

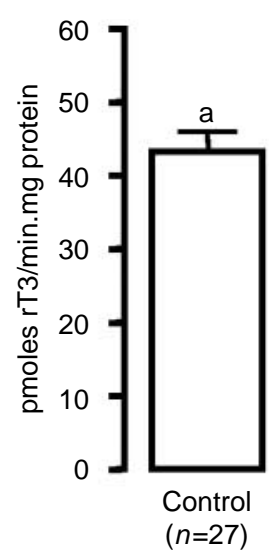

Kidney D1

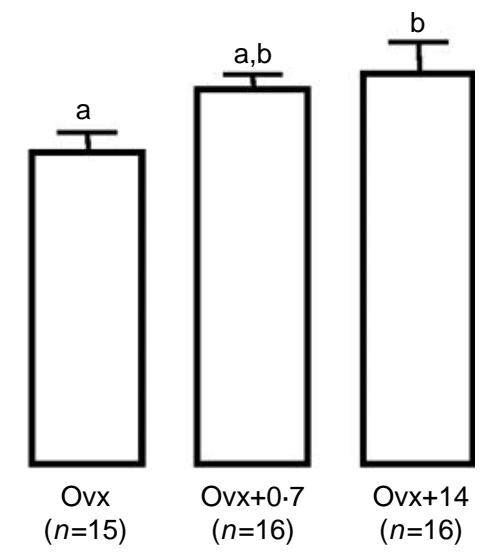

Pituitary D1

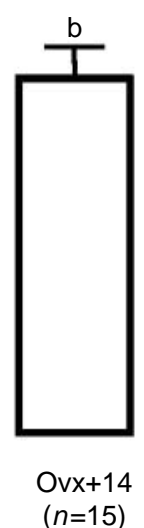

D

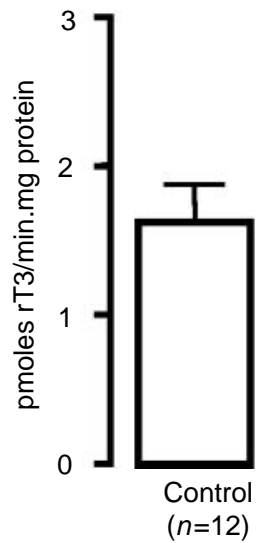

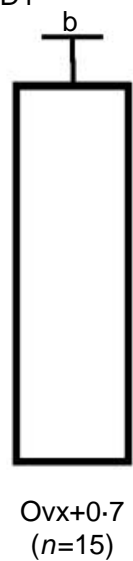

Thyroid D1

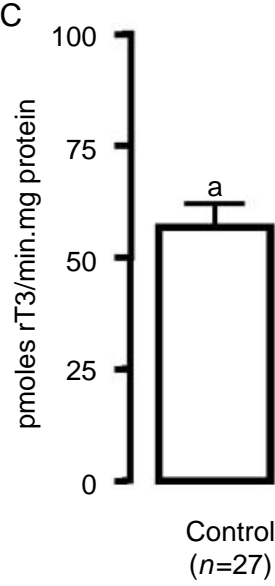

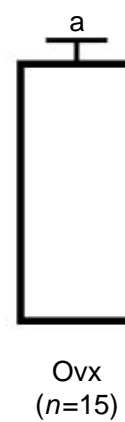

$(n=15)$

Figure 5 Type 1 iodothyronine deiodinase activity in liver (A), kidney (B), thyroid (C), and pituitary (D) of female sham-operated (control) and ovariectomized rats treated with vehicle $(\mathrm{Ovx})$ or with $0 \cdot 7(\mathrm{Ovx}+0 \cdot 7)$ or $14(\mathrm{Ovx}+14) \mu \mathrm{g} / 100 \mathrm{~g}$ bw per day estradiol benzoate, subcutaneously for 21 days. Data are shown as means \pm S.E.M.; $n=$ total number of rats. Different letters indicate statistically significant differences for: liver, $P<0 \cdot 05$; kidney, $P<0 \cdot 05$; thyroid, $P<0 \cdot 05$.

reaching the adult value in 21-day-old rats and that the intrapituitary T4-5' -monodeiodination rate was higher in 2 and 4-day-old rats and fell to the adult value by 30 days of age. However, the present study shows liver, renal, thyroid, and pituitary D1 activities to be lower in the male pre-pubertal rats than in the adult rats. Serum T3 may be decreased in adult males due to their higher hepatic D1, which has recently been shown to also participate in the clearance of serum T3 (Schneider et al. 2006). The decreased serum T3 might contribute to the increased serum TSH, which in turn can lead to increased thyroid D1 activity, as previously demonstrated (Köhrle 1999). In fact, increased thyroid D1 might counteract the increased T3 clearance and sustain serum T3 to a certain extent.

Although thyroid hormone-induced increases in D1 activity and/or mRNA levels are well documented in rats (Bianco et al. 2002), we found higher D1 activity in male adult than in pre-pubertal rats, despite lower serum T3. This suggests that directly or indirectly the increase in testicular hormonal activity could act as a potent stimulus of D1 activity. In the female groups, liver and renal D1 activities were higher in pre-pubertal than in adult rats, without significant differences in thyroid and pituitary activities. In fact, after sexual maturation, liver and renal D1 activities seem to be down-regulated in females. Since estrogen seems to positively modulate D1 activity and ovariectomy does not promote any significant change in female hepatic and renal D1, it is tempting to speculate that other factors, besides gonadal hormones, could be modulating D1 activity during murine maturation in the female.

The liver, renal, thyroid, and pituitary D1 activities were significantly lower in female than in male adult rats, corroborating part of earlier reports (Harris et al. 1979, Donda et al. 1990, Santini et al. 1994, Miyashita et al. 1995) 
that demonstrate decreased liver D1 activity in females, without differences in kidney. However, this data differ from a previous report of lower hepatic D1 activity in males and no sex-related differences in thyroid D1 activity (Corrêa da Costa et al. 2001). Donda et al. (1990) showed lower pituitary D1 activity in male than in female adult rats, which was not observed in the present study. These controversial results may be related to different rat strains and/or different deiodinase activity determination methodologies.

Thyroid hormones are the main known regulators of liver and renal D1 activity (Köhrle 1999, Koenig 2005). We did not find differences in serum $\mathrm{T} 4$ between female and male adult rats, but serum T3 was lower in males than in females, regardless of the higher hepatic and renal D1 activities in males, so this would not be the explanation for sex-related differences. Moreover, Miyashita et al. (1995) demonstrated that, in thyroidectomized adult rats, liver D1 activity was lower in females than in males, suggesting that sex-related differences in liver D1 activity are independent of thyroid status and could be due to the presence of testosterone in male rats. Maia et al. (2003) suggested that, in human, the skeletal muscle D2 activity could be responsible for a major part of the peripheric T4 to T3 deiodination. It is doubtful whether the same can be proposed for the rat, since previous evaluations were unable to detect D2 activity in the rat skeletal muscle (St Germain et al. 2005).

Body weight was significantly decreased in orchiectomized rats when compared with the control group. This finding agrees with the results found by Ke et al. (2001) and Moreau et al. (2001). The absolute and relative weights of the thyroid and pituitary were not changed in castrated male rats. This data disagree with Banu et al. (2001), who observed that orchiectomy decreased the absolute and relative thyroid weights of 60-day-old rats that were gonadectomized at day 10 post partum, and of 160-day-old rats gonadectomized at day 120 post partum. This discordance is probably due to differences in the ages of the animals used and the period of castration. Therefore, data obtained in the present study show that androgens are important for body weight gain but do not affect thyroid and pituitary weights, at least during a period of 3 weeks after castration.

The present study corroborates the finding that serum total T3 and T4 are unaltered in orchiectomized animals, in agreement with Christianson et al. (1981). Christianson et al. (1981) reported that serum TSH concentration in adult male rats is androgen mediated. Our data of orchiectomy-induced decrease in serum TSH confirm this finding. Farbota et al. (1987) and Banu et al. (2001) found similar alterations and reported a stimulatory effect of testosterone on TSH secretion in both male and female rats.

Orchiectomy and its associated decrease of serum testosterone resulted in a decrease of hepatic and renal D1 activities, without changes in thyroid or pituitary D1 activity. A decrease in hepatic D1 activity in orchiectomized rats has been reported previously (Harris et al. 1979, Miyashita et al. 1995, Lisbôa et al. 2001). Since D1 activity is dependent on thyroid hormone levels, the decreased liver and kidney D1 in castrated male adult rats that have normal plasma T3 and T4 indicates a direct stimulatory action of androgens on D1 activity, at least in liver and kidney, as do Miyashita et al. (1995) findings of increased D1 mRNA levels in cultured rat hepatocytes exposed to testosterone. Recent findings in our laboratory also confirm the stimulatory effect of androgens on hepatic and renal D1 activity (Fortunato et al. 2006).

In rats, a great proportion of $\mathrm{T} 4$ is deiodinated in the thyroid generating approximately $40-50 \%$ of circulating T3 (Bianco et al. 2002). Thus, despite their lower serum TSH, the unchanged thyroidal D1 activity and decreased hepatic D1 could explain the normal serum T3 levels in orchiectomized rats. Previously, castration has been shown to induce an increment in male pituitary D1 activity (Lisbôa et al. 2001). However, these data do not agree with our finding of unchanged pituitary D1 activity, but different methodologies were used in these two studies.

As far as we know, this is the first report showing that although androgens can stimulate hepatic and kidney deiodinase, its lack does not affect thyroid D1 activity, at least after a 3-week castration period.

In female adult rats, body weight gain was significantly increased by ovariectomy. Moreover, in ovariectomized rats treated with estradiol, the body weight gain was less than in the control animals. This result corroborates data of Kimura et al. (2002) and Meli et al. (2004) that suggest a lipolytic effect of estrogen. Estrogens seem to have a central action, inhibiting the neuropeptide $\mathrm{Y}$ and consequently food intake (Meli et al. 2004). Furlanetto et al. (1999) reported increased proliferation of FRTL-5 cells after their exposure to estradiol. However, our in vivo study did not reveal changes in thyroid weight among the adult female groups. These data obtained 21 days after ovariectomy disagree with Banu et al. (2001), who observed that ovariectomy decreased the absolute thyroid weights of 60-day-old rats that were castrated at day 10 post partum, and of 160 -day-old rats castrated at day 120 post partum. The discordance may be due to the differences in the ages of the animals and the period of castration between Banu et al. and our observations. A dose-dependent increase of pituitary weight was found in the ovariectomized estradioltreated rats; this increase is to be expected considering the hypertropic effect of estrogen on lactotropic cells.

In this context, it should be noted that no significant changes in serum TSH was detected among the female groups. Chen \& Walfish (1978) and Lisbôa et al. (1997) have reported that estradiol treatment of castrated females promotes an increase in serum TSH, but neither we nor Christianson et al. (1981) found a similar increase in serum TSH.

Our results confirm that serum total $\mathrm{T} 4$ concentration is not altered by ovariectomy (Christianson et al. 1981, Lisbôa et al. 1997), but there is a small significant decrease in serum T3, also reported by Lima et al. (2006). The hepatic, renal, thyroid, and pituitary D1 activities were unchanged in ovariectomized rats. After treatment of Ovx rats with estradiol, serum T4 diminished (as in earlier reports of 
Chen \& Walfish 1978 and Harris et al. 1979), but serum T3 returned to control values. This correlates with the increase in hepatic and renal D1 activity seemingly induced by the estradiol treatment. Thyroid D1 also was increased by estrogen treatment and might contribute to the increase in T3/T4 serum ratio. The pituitary D1 activity was unaffected by estradiol treatment. Corroborating our data, Miyashita et al. (1995) also did not find any changes in hepatic D1 activity and mRNA in castrated female rats, and Harris et al. (1979) found an increase in hepatic D1 activity of ovariectomized rats treated with estradiol. The results of Lisbôa et al. (1997, 2001) on liver D1 activity in ovariectomized rats are discordant, but they agree concerning the stimulatory effect of estradiol replacement on hepatic and thyroid D1.

In summary, in adult males, gonadal hormones seem to exert a significant positive influence on hepatic (and renal) D1 activity. In contrast, a decrease in gonadal hormones does not appear to affect adult female hepatic, kidney, or thyroid D1 activity, although they can be stimulated by exogenous estradiol treatment. The comparison between pre-pubertal and adult rats suggests that $\mathrm{T} 3$ is not the only or main stimulus of D1 activity and that other factors besides thyroid and gonadal hormones, can modulate D1 activity during murine maturation.

\section{Acknowledgements}

We are grateful for the technical assistance of Norma Lima de Araújo Faria, Advaldo Nunes Bezerra, and Wagner Nunes Bez- erra. Norma L A Faria was the recipient of a fellowship from $\mathrm{CNPq}$ and Michelle P Marassi was the recipient of a fellowship from Coordenação de Aperfeiçoamento de Pessoal de Nivel Superior (CAPES) during the present study.

\section{Funding}

This work was supported by grants from Fundação Carlos Chagas Filho de Amparo à Pesquisa do Estado do Rio de Janeiro (FAPERJ) and Conselho Nacional de Desenvolvimento Científico e Tecnológico (CNPq). The authors declare that there is no conflict of interest that would prejudice the impartiality of this scientific work.

\section{References}

Banu SK \& Aruldhas MM 2002 Sex steroids regulate TSH-induced thyroid growth during sexual maturation in Wistar rats. Experimental and Clinical Endocrinology and Diabetes 110 37-42.

Banu SK, Arosh JA, Govindarajulu P \& Aruldhas MM 2001 Testosterone and estradiol diferentially regulate thyroid growth in Wistar rats from immature to adult age. Endocrine Research 27 447-463.

Banu SK, Govindarajulu P \& Aruldhas MM 2002 Developmental profiles of TSH, sex steroids, and their receptors in the thyroid and their relevance to thyroid growth in immature rats. Steroids 67 137-144.
Berry MJ, Kieffer JD, Harney JW \& Larsen PR 1991 Selenocysteine confers the biochemical properties characteristic of the type I iodothyronine deiodinase. Journal of Biological Chemistry 266 14155-14158.

Bianco AC, Salvatore D, Gereben B, Berry MJ \& Larsen PR 2002 Biochemistry, cellular and molecular biology, and physiological roles of the iodothyronine selenodeiodinases. Endocrine Reviews 23 38-89.

Bradford MM 1976 A rapid and sensitive method for the quantification of microgram quantities of proteins utilizing the protein-dye binding. Analytical Biochemistry 72 248-254.

Chen HJ 1984 Age and sex difference in serum and pituitary thyrotropin concentrations in the rat: influence by pituitary adenoma. Experimental Gerontology 19 1-6.

Chen HJ \& Walfish PG 1978 Effects of estradiol benzoate on thyroid-pituitary function in female rats. Endocrine Society 103 1023-1030.

Cheron RG, Kaplan MM \& Larsen PR 1980 Divergent changes of thyroxine$5^{\prime}$-monodeiodination in rat pituitary and liver during maturation. Endocrinology 106 1405-1409.

Christianson D, Roti E, Vagenakis AG \& Braverman LE 1981 The sex-related difference in serum thyrotropin concentration is androgen mediated. Endocrinology 108 529-535.

Corrêa da Costa VM, Moreira DG \& Rosenthal D 2001 Thyroid function and aging: gender-related differences. Journal of Endocrinology 171 193-198.

Dohler KD \& Wuttke W 1975 Changes with age in levels of serum gonadotropins, prolactin, and gonadal steroids in prepubertal male and female rats. Endocrinology 97 898-907.

Donda A, Reymond MJ, Zürich MG \& Lemarchand-Béraud TH 1987 Influence of sex and age on $\mathrm{T} 3$ receptors and $\mathrm{T} 3$ concentration in the pituitary gland of the rat: consequences on TSH secretion. Molecular and Cellular Endocrinology 54 29-34.

Donda A, Reymond F, Rey F \& Lemarchand-Béraud T 1990 Sex steroids modulate the pituitary parameters involved in the regulation of TSH secretion in the rat. Acta Endocrinologica 122 577-584.

Farbota L, Hofmann C, Oslapas R \& Paloyan E 1987 Sex hormone modulation of serum TSH levels. Surgery 102 1081-1087.

Fortunato RS, Marassi MP, Chaves EA, Nascimento JH, Rosenthal D \& Carvalho DP 2006 Chronic administration of anabolic androgenic steroid alters murine thyroid function. Medicine and Science in Sports and Exercise 38 256-261.

Fukuda H, Greer M, Roberts L, Allen CE, Critcholow V \& Wilson M 1975 Nyctohemeral and sex-related variations in plasma thyrotropin, thyroxine, and triiodothyronine. Endocrinology 97 1424-1430.

Furlanetto TW, Nguyen LQ \& Jameson JL 1999 Estradiol increases proliferation and down-regulates the sodium/iodide symporter gene in FRTL-5 cells. Endocrinology 140 5705-5711.

Gong DW, Murayama Y, Yamazoe R \& Kato R 1992 Hepatic triiodothyronine sulfation and its regulation by growth hormone and triiodothyronine in rats. Journal of Biochemistry 112 112-116.

Greeley GH, Lipton MA \& Kizer JS 1983 Serum thyroxine, triiodothyronine, and TSH levels and TSH release after TRH in aging male and female rats. Endocrine Research Communications 9 169-177.

Harris ARC, Vagenakis AG \& Braverman LE 1979 Sex-related differences in outer ring monodeiodination of thyroxine and $3,3^{\prime}, 5^{\prime}$-triiodothyronine by rat liver homogenates. Endocrinology 104 645-652.

Ke HZ, Crawford DT, Qi H, Chidsey-Frink KL, Simmons HA, Li M, Jee WS \& Thompson DD 2001 Long-term effects of aging and orchidectomy on bone and body composition in rapidly growing male rats. Journal of Musculoskeletal and Neuronal Interactions 1 215-224.

Kimura M, Irahara M, Yasui T, Saito S, Tezuka M, Yamano S, Kamada M \& Aono T 2002 The obesity in bilateral ovariectomized rats is related to a decrease in the expression of leptin receptors in the brain. Biochemical and Biophysical Research Communications 290 1349-1353.

Koenig RJ 2005 Regulation of type 1 iodothyronine deiodinase in health and disease. Thyroid 15 835-840.

Köhrle J 1999 Local activation and inactivation of thyroid hormones: the deiodinase family. Molecular and Cellular Endocrinology 151 103-119.

Köhrle J, Schomburg L, Drescher S, Fekete E \& Bauer K 1995 Rapid stimulation of type I $5^{\prime}$-deiodinase in rat pituitaries by $3,3^{\prime}, 5$-triio-Lthyronine. Molecular and Cellular Endocrinology 108 17-21. 
Lima LP, Barros IA, Lisboa PC, Araujo RL, Silva AC, Rosenthal D, Ferreira AC \& Carvalho DP 2006 Estrogen effects on thyroid iodide uptake and thyroperoxidase activity in normal and ovariectomized rats. Steroids $\mathbf{7 1}$ 653-659.

Lisbôa PC, Curty FH, Moreira RM \& Pazos-Moura CC 1997 Effects of estradiol benzoate on $5^{\prime}$-iodothyronine deiodinase activities in female rat anterior pituitary gland, liver and thyroid gland. Brazilian Journal of Medical and Biological Research 30 1479-1484.

Lisbôa PC, Curty FH, Moreira RM, Oliveira KJ \& Pazos-Moura CC 2001 Sex steroids modulate rat anterior pituitary and liver iodothyronine deiodinase activities. Hormone and Metabolic Research 33 532-535.

Maia AL, Kim BW, Huang SA, Harney JW \& Larsen PR 2003 Type 2 iodothyronine deiodinase is the major source of plasma $T_{3}$ in euthyroid humans. Journal of Clinical Investigation 115 2524-2533.

Meijs-Roelofs HM, Uilenbroek JT, Jong FH \& Welschen R 1973 Plasma estradiol-17 $\beta$ and its relationship to serum follicle-stimulating hormone in immature female rats. Journal of Endocrinology 59 295-304.

Meli R, Pacilio M, Raso GM, Esposito E, Coppola A, Nasti A, Carlo CD, Nappi C \& Carlo RD 2004 Estrogen and raloxifene modulate leptin and its receptor in hypothalamus and adipose tissue from ovariectomized rats. Endocrinology 145 3115-3121.

Miyashita K, Murakami M, Iriuchijima T, Takeuchi T \& Mori M 1995 Regulation of rat type I iodothyronine deiodinase mRNA levels by testosterone. Molecular and Cellular Endocrinology 115 161-167.

Moreau MF, Libouban H, Legrand E, Basle MF, Audran M \& Chappard D 2001 Lean, fat and bone masses are influenced by orchiectomy in the rat. A densitometric X-ray absorptiometric study. Journal of Musculoskeletal and Neuronal Interactions 1 209-213.

Moreira DG, Marassi MP, Corrêa da Costa VM, Carvalho DP \& Rosenthal D 2005 Effects of ageing and pharmacological hypothyroidism on pituitary-thyroid axis of Dutch-Miranda and Wistar rats. Experimental Gerontology 40 330-334.

Rapp JP \& Pyun LL 1974 A sex difference in plasma thyroxine and thyroid stimulating hormone in rats. Proceedings of the Society for Experimental Biology and Medicine 146 1021-1023.

Santini F, Hurd RE, Lee B \& Chopra IJ 1994 Sex-related differences in iodothyronine metabolism in the rat: evidence for differential regulation among various tissues. Metabolism: Clinical and Experimental 43 793-797.

Scheithauer BW, Sano T, Kovacs KT, Young JRWF, Ryan N \& Randall RV 1990 The pituitary gland in pregnancy: a clinicopathologic and immunohistochemical study of 69 cases. Mayo Clinic Proceedings 65 461-474.

Schneider MJ, Fiering SN, Thai B, Wu SY, St Germain E, Parlow AF, St Germain DL \& Galton VA 2006 Targeted disruption of the type 1 selenodeiodinase gene (Dio1) results in marked changes in thyroid hormone economy in mice. Endocrinology 147 580-589.

St Germain DL 1994 Iodothyronine deiodinases. Trends in Endocrinology and Metabolism 5 36-42.

St Germain DL, Hernandez A, Schneider MJ \& Galton VA 2005 Insights into the role of deiodinases from studies of genetically modified animals. Thyroid 15 905-915.

Visser TJ, Kaptein E, Glatt H, Bartsch I, Hagen M \& Coughtrie MWH 1998 Characterization of thyroid hormone sulfotransferases. Chemico-Biological Interactions 109 279-291.

Received in final form 19 October 2006

Accepted 23 October 2006

Made available online as an Accepted Preprint 30 October 2006 